\title{
Pengaruh Pengawasan dan Penilaian Kinerja Terhadap Produktivitas Kerja Pada PT. Remco Palembang
}

\author{
Fitriana $^{1}$, Emma $^{\text {Lilianti }}{ }^{2}$ \\ ${ }^{1}$ Akuntansi, Fakultas Ekonomi, Univ. PGRI Palembang, ananfitri995@gmail.com \\ ${ }^{2}$ Akuntansi, Fakultas Ekonomi, Univ. PGRI Palembang emmaliliantiok@gmail.com
}

\begin{abstract}
ABSTRAK
Tujuan penelitian untuk mengetahui pengaruh pengawasan dan penilaian kinerja terhadap produktivitas kerja karyawan Pada PT. Remco Palembang. Teknik pengumpulan data yang dilakukan dalam penelitian ini adalah observasi, wawancara dan penyebaran kuesioner kepada 60 orang karyawan. Teknik analisis data menggunakan analisis regresi linear berganda, koefisien determinasi dan pengujian hipotesis dengan menggunakan uji $F$ dan uji t. Berdasarkan pengolahan data diperoleh persamaan regresi linear berganda $Y=3,250+0,271 \mathrm{X}_{1}+0,656 \mathrm{X}_{2}$ dan hasil koefisien determinasi $R^{2}$ sebesar 0,485 atau $48,5 \%$ dengan begitu pengawasan dan penilaian kinerja mempengaruhi produktivitas kerja sebesar $48,5 \%$ sedangkan sisanya $51,5 \%$ dipengaruhi oleh faktor-faktor lain yang tidak diteliti dalam penelitian ini. Hasil uji $F$ diperoleh nilai signifikan 0,000 kurang dari 0,05 artinya secara simultan, pengawasan dan penilaian kinerja berpengaruh signifikan terhadap produktivitas kerja. Hasil uji t variabel pengawasan diperoleh nilai signifikan sebesar 0,006 kurang dari 0,05 artinya secara parsial, pengawasan berpengaruh signifikan terhadap produktivitas kerja dan variabel penilaian kinerja diperoleh nilai signifikan sebesar 0,000 kurang dari 0,05 artinya secara parsial, penilaian kinerja berpengaruh signifikan terhadap produktivitas kerja.
\end{abstract}

Kata Kunci: Pengawasan, Penilaian Kinerja, Produktivitas Kerja.

\begin{abstract}
The research objective is to determine the effect of supervision and performance evaluation on employee productivity at PT. Remco Palembang. Data collection techniques used in this study were observation, interviews and questionnaires to 60 employees. Data analysis techniques used multiple linear regression analysis, coefficient of determination and hypothesis testing using the $F$ test and $t$ test. Based on data processing obtained by multiple linear regression equation $Y=3,250+0,271 X$ $+0,656 X \_2$ and the results of the determination coefficient $R \wedge 2$ of 0.485 or $48.5 \%$ so that supervision and performance evaluation affect work productivity by $48.5 \%$ while the remaining $51.5 \%$ is influenced by other factors not examined in this study. $F$ test results obtained a significant value of 0,000 less than 0.05 meaning that simultaneously, supervision and performance evaluation have a significant effect on work productivity. T-test results of the supervision variable obtained a significant value of 0.006 less than 0.05 meaning that partially, supervision has a significant effect on work productivity and performance appraisal variables obtained a significant value of 0,000 less than 0.05 meaning that partially, performance appraisal has a significant effect on work productivity .
\end{abstract}

Keywords: Supervision, Performance Appraisal, Work Productivity.

\section{A. PENDAhULUAN}

Keberhasilan

ditentukan dari kualitas tenaga kerja

dan sistem yang ada dalam

perusahaan. Tenaga kerja memegang

peranan yang sangat penting karena

tenaga kerja merupakan faktor utama dalam melaksanakan kegiatan perusahaan. Pada umumnya tujuan perusahaan melakukan kegiatan untuk mendapatkan hasil yang maksimal guna kelangsungan hidup suatu perusahaan. 
Produktivitas kerja diperlukan untuk mencapai tujuan yang telah ditetapkan. Produktivitas kerja sering diartikan sebagai sikap yang senantiasa mempunyai pandangan bahwa metode kerja hari ini harus lebih baik dari pada metode kerja hari kemarin dalam hasil yang dapat diraih esok hari harus lebih banyak atau lebih bermutu daripada hasil yang diraih hari ini. Hal ini sama dengan yang dikemukakan oleh Husein (2013:9) bahwa produktivitas adalah sikap mental yang selalu berpandangan bahwa mutu kehidupan hari ini harus lebih baik dari kemarin.

Seorang karyawan dikatakan produktif jika dalam melakukan pekerjaan mencapai standar pekerjaan yang telah ditetapkan perusahaan atau melampaui target yang diberikan sehingga perusahaan dapat mencapai tujuan yang telah ditetapkan. Hal ini sama dengan yang dikemukakan oleh Karmila (2018) dalam penelitiannya bahwa ada pengaruh yang siginifikan antara pengawasan dan penilaian kinerja terhadap produktivitas kerja. Oleh karena itu, pihak perusahaan harus melakukan pengawasan dan penilaian kinerja yang lebih ketat lagi agar tidak terjadinya penyimpangan ataupun hal-hal yang tidak diinginkan.

Pelaksanaan pengawasan sangatlah penting dalam sebuah perusahaan terutama terhadap karyawan. Pada dasarnya setiap instruksi yang disampaikan kepada bawahan harus diawasi oleh pimpinan sehingga pimpinan mampu mengambil tindakan apabila terjadi kesalahan dan kelalaian akan tugas yang dijalani oleh para karyawannya sehingga produktivitas karyawan semakin meningkat. Hal ini sama dengan yang dikemukakan oleh Mockler dalam Handoko (2014:358) bahwa pengawasan adalah suatu usaha sistematik untuk menetapkan standar pelaksanaan dengan tujuan-tujuan perencanaan, merancang sistem informasi umpan balik, membandingkan kegiatan nyata dengan standar yang ditetapkan sebelumnya serta mengambil tindakan koreksi yang diperlukan untuk menjamin bahwa sumber daya perusahaan digunakan dengan secara efisien dalam mencapai tujuan perusahaan.

Selain pengawasan yang harus dilakukan perusahaan adalah penilaian kinerja. Dengan melakukan penilaian kinerja perusahaan dapat mengetahui munculnya hambatan yang terjadi dan secepat mungkin diantisipasi agar dapat meningkatkan produktivitas kerja karyawan demi kelancaran kegiatan perusahaan. Mangkunegara (2011:67) mengatakan penilaian kinerja adalah suatu proses penilaian prestasi kerja pegawai yang dilakukan pimpinan perusahaan secara sistematik berdasarkan pekerjaan yang ditugaskan kepadanya.

Perusahaan ini cenderung menggunakan pekerja lapangan bukan di kantor sesuai dengan sifat produk yang dihasilkan yaitu bidang produksi karet. Metode pengawasan yang dilakukan oleh perusahaan ini yaitu metode pengawasan langsung yang dilakukan oleh kepala bagian dan perusahaan ini juga melakukan penilaian kinerja pada setiap 6 bulan sekali untuk mengetahui keberhasilan dan kegagalan karyawan dalam melakukan pekerjaan yang telah ditetapkan

Pengawasan dan penilaian kinerja terhadap karyawan bagian produksi sudah dilakukan namun berdasarkan hasil observasi lapangan masih ditemui fenomena di lapangan yaitu masih adanya kendala dalam melaksanakan penilaian kinerja seperti terlibatnya emosional dari penilaian sehingga mengakibatkan penilaian 
menjadi kurang objektif, masih adanya beberapa karyawan berbincangbincang saat sedang bekerja dan masih adanya karyawan yang terlambat saat waktu masuk kerja setelah jam istirahat.

\section{B. KAJIAN TEORI \\ Pengawasan}

Handayaningrat

(2010:141)

menjelaskan pengawasan adalah suatu proses dimana pimpinan ingin mengetahui apakah hasil pelaksanaan pekerjaan dilakukan oleh bawahannya sesuai dengan rencana, perintah, tujuan atau kebijaksanaan yang telah ditetapkan, sedangkan Handoko (2009:361) menjelaskan pengawasan merupakan pemeriksaan terhadap kegiatan yang telah dilaksanakan dengan cara membandingkan pekerjaan yang sesuai dengan yang diharuskan.

\section{Tujuan Pengawasan}

Sayuti

mengelompokkan tujuan pengawasan menjadi beberapa tujuan yaitu:

1) Meningkatkan kinerja organisasi secara kontinyu

2) Meningkatkan efisiensi dan keuntungan bagi organisasi dengan menghilangkan pekerjaan yang tidak perlu atau mengurangi penyalahgunaan alat atau bahan

3) Menilai derajat pencapaian rencana kerja dengan hasil aktual yang dicapai dan dapat dipakai sebagai dasar pemberian kompensasi bagi seorang pegawai

4) Mengkordinasikan beberapa elemen tugas atau program yang dijalankan

5) Membantu karyawan untuk melaksanakan tugasnya agar lebih efisien.

\section{Penilaian Kinerja.}

Suwatno (2013:196) mengatakan penilaian kinerja adalah suatu sistem formal dan terstruktur yang digunakan untuk mengukur, menilai, dan mempengaruhi sifat-sifat yang berkaitan dengan pekerjaan, perilaku, dan hasil termasuk tingkat ketidakhadiran, sedangkan Wibowo (2011:7) mengatakan kinerja adalah hasil kerja yang mempunyai makna luas bukan hanya hasil kerja tetapi termasuk bagaimana proses pekerjaan berlangsung.

\section{Faktor Yang Mempengaruhi Penilaian Kinerja}

Notoatmodjo (2009:124-125) mengelompokkan ada beberapa faktor yang mempengaruhi penilaian kinerja yaitu:

1) Variabel Individu

Variabel individu terdiri dari pemahaman terhadap pekerjaannya, pengalalaman kerja, latar belakang keluarga, tingkat sosial ekonomi, faktor umur dan jenis kelamin.

2) Variabel Organisasi

Variabel organisasi yang terdiri dari kepemimpinan, desain pekerjaan, sumber daya yang lain dan struktur organisasi.

3) Variabel psikologis

Variabel yang terdiri dari persepsi terhadap pekerjaan, sikap terhadap pekerjaan, motivasi dan kepribadian

\section{Produktivitas Kerja}

Hasibuan

(2010:128)

mengemukakan produktivitas kerja merupakan perbandingan hasil yang dimiliki baik secara perorangan ataupun tim didalam suatu organisasi atau perusahaan, sedangkan Sinungan (2014:17) mengemukakan produktivitas kerja adalah suatu konsep yang bersifat universal yang bertujuan untuk menyediakan lebih banyak barang dan jasa yang akan 
digunakan oleh banyak manusia dengan menggunakan sumber-sumber riil yang semakin sedikit.

\section{Faktor Yang Mempengaruhi Produktivitas Kerja}

Sutrisno

$(2015: 103)$

mengelompokkan ada beberapa faktor yang mempengaruhi produktivitas kerja yaitu:

1) Pelatihan dimaksud untuk melengkapi karyawan dengan keterampilan dan cara yang tepat untuk menggunakan peralatan kerja. Latihan kerja diperlukan bukan saja sebagai pelengkap akan tetapi sekaligus untuk memberikan dasardasar pengetahuan

2) Mental dan kemampuan fisik karyawan. Keadaan mental dan fisik karyawan merupakan hal yang sangat penting untuk menjadi perhatian bagi perusahaan sebab keadaan fisik dan mental mempunyai hubungan yang erat dengan produktivitas kerja karyawan

3) Hubungan antara atasan dan bawahan. Hubungan atasan dan bawahan akan mempengaruhi kegiatan yang dilakukan sehari-hari. Bagaimana pandangan atasan terhadap karyawan sejauh mana karyawan diikutsertakan dalam penentuan tujuan.

\section{Penelitian Terdahulu}

Penelitian terdahulu merupakan dasar atau acuan berupa teori-teori atau temuan melalui hasil penelitian sebelumnya yang merupakan hal Yang sangat perlu dan dapat dijadikan sebagai data pendukung. Tabal berikut menyajikan penelitian terdahulu yang penulis gunakan sebagai referensi.

Tabel Penelitian Terdahulu

\begin{tabular}{|c|c|c|c|}
\hline No. & $\begin{array}{l}\text { Nama } \\
\text { (Tahun) }\end{array}$ & Judul & Hasil \\
\hline 1. & $\begin{array}{l}\text { Karmila } \\
(2018)\end{array}$ & $\begin{array}{l}\text { Pengaruh Pengawasan dan } \\
\text { Penilaian Kinerja Terhadap } \\
\text { Produktivitas Kerja Karyawan } \\
\text { Perkebunan (Studi Kasus } \\
\text { Karyawan Bagian Produksi } \\
\text { Pada PTPN V SEl Buatan). }\end{array}$ & $\begin{array}{l}\text { Ada pengaruh yang } \\
\text { signifikan antara } \\
\text { pengawasan dan penilaian } \\
\text { kinerja terhadap } \\
\text { produktivitas kerja. }\end{array}$ \\
\hline 2. & $\begin{array}{l}\text { Legawati } \\
(2014)\end{array}$ & $\begin{array}{l}\text { Pengaruh } \\
\text { Terhadap Produktivitas Kerja } \\
\text { Karyawan } \text { Pabrik (Kasus } \\
\text { Karyawan Bagian Produksi } \\
\text { PT. Pelita Agung Agrindustri } \\
\text { di Duri). }\end{array}$ & $\begin{array}{lr}\text { Ada pengaruh } & \text { yang } \\
\text { signifikan } & \text { antara } \\
\text { pengawasan terhadap } & \text { produktivitas kerja kerja. }\end{array}$ \\
\hline 3. & $\begin{array}{l}\text { Murnawa } \\
\text { ntika } \\
(2014)\end{array}$ & $\begin{array}{l}\text { Pengaruh Pengawasan } \\
\text { Terhadap Produktivitas Kerja } \\
\text { Karyawan Pada CV. Putra } \\
\text { Kaltim Di Samarinda. }\end{array}$ & \begin{tabular}{lr} 
Ada pengaruh & yang \\
signifikan & antara \\
pengawasan terhadap & \multicolumn{2}{l}{ produktivitas kerja. }
\end{tabular} \\
\hline 4. & $\begin{array}{l}\text { Dona } \\
(2018)\end{array}$ & $\begin{array}{l}\text { Pengaruh Penilaian kinerja } \\
\text { Terhadap Produktivitas Kerja } \\
\text { pegawai dikantor BPKAD } \\
\text { Kabupaten Kurai Timur. }\end{array}$ & $\begin{array}{l}\text { Ada pengaruh yang } \\
\text { signifikan antara penilaian } \\
\text { kinerja terhadap } \\
\text { produktivitas kerja. }\end{array}$ \\
\hline 5. & $\begin{array}{l}\text { Bintang } \\
(2016)\end{array}$ & $\begin{array}{l}\text { Pengaruh } \begin{array}{r}\text { Penilaian Kinerja } \\
\text { Dan }\end{array} \\
\text { Pengembangan }\end{array}$ & $\begin{array}{l}\text { Ada pengaruh yang } \\
\text { signifikan antara penilaian }\end{array}$ \\
\hline
\end{tabular}




\begin{tabular}{|l|l|l|l|}
\hline & $\begin{array}{l}\text { Karyawan } \\
\text { Produktivitas }\end{array}$ & Terhadap & kinerja Karyawan \\
(Kasus PT Bank Sumut & produktivitas kerja. \\
Cabang Sidikalang). & \\
\hline
\end{tabular}

\section{METODE PENELITIAN}

Sugiyono (2017:2) menjelaskan metode penelitian merupakan cara ilmiah untuk mendapatkan data dengan tujuan dan kegunaan tertentu. Penelitian ini menggunakan metode penelitian kuantitatif dengan pendekatan deskriptif dan assosiatif. Sugiyono (2017:8) menjelaskan penelitian kuantitatif merupakan metode penelitian yang berlandaskan filsafat yang digunakan untuk meneliti pada sampel pengumpulan data menggunakan instrumen penelitian, analisis data bersifat statistik dengan tujuan untuk menguji hipotesis yang telah ditetapkan. Sugiyono

\section{Definisi Operasional Variabel}

Sugiyono (2017:39) mengatakan definisi operasional variabel merupakan suatu atribut seseorang atau kegiatan yang mempunyai variasi
(2017:35) menjelaskan pendekatan deskriptif merupakan metode yang dilakukan untuk mengetahui letak variabel mandiri baik hanya satu variabel atau lebih tanpa membuat perbandingan variabel dan mencari hubungan dengan variabel lain. Sugiyono (2017:37) menjelaskan pendekatan assosiatif merupakan suatu rumusan masalah penelitian yang bersifat menanyakan hubungan antara dua variabel atau lebih.

Variabel dalam penelitian ini meliputi variabel bebas yaitu pengawasan dan penilaian kinerja dan variabel terikat yaitu produktivitas kerja.

tertentu yang telah ditetapkan oleh peneliti untuk dipelajari kemudian ditarik kesimpulannya.

Tabel dibawah menyajikan definisi operasional dalam penelitian ini.

Tabel Definisi Operasional Variabel

\begin{tabular}{|c|c|c|c|c|}
\hline No & Variabel & Definisi & Indikator & Skala \\
\hline 1. & $\begin{array}{l}\text { Pengawasan } \\
\left(X_{1}\right)\end{array}$ & $\begin{array}{l}\text { Adalah pemeriksaan apakah } \\
\text { sesuatu terjadi sesuai dengan } \\
\text { rencana instruksi yang di } \\
\text { keluarkan dan prinsip-prinsip } \\
\text { yang telah di tentukan. } \\
\text { Sukarman (2011:111) }\end{array}$ & $\begin{array}{l}\text { a. Standar pelaksanaan } \\
\text { b. Pengukuran pelaksanaan } \\
\text { kegiatan } \\
\text { c. Kinerja pegawai } \\
\text { d. Pembandingan pelaksanaan } \\
\text { kegiatan } \\
\text { e. Pengambilan tindakan koreksi }\end{array}$ & $\begin{array}{l}1,2 \\
3.4 \\
5,6 \\
7,8 \\
9,10\end{array}$ \\
\hline 2. & $\begin{array}{l}\text { Penilaian } \\
\text { Kinerja } \\
\left(X_{2}\right)\end{array}$ & $\begin{array}{l}\text { Adalah performance sebagai } \\
\text { hasil atau prestasi kerja yang } \\
\text { mempunyai makna yang lebih } \\
\text { luas bukan hanya hasil kerja } \\
\text { tetapi termasuk bagaimana } \\
\text { proses pekerjaan berlangsung. } \\
\text { Wibowo (2011:7) }\end{array}$ & $\begin{array}{l}\text { a. Tujuan } \\
\text { b. Standar } \\
\text { c. Umpan Balik } \\
\text { d. Alat dan Sarana } \\
\text { e. Kompetensi } \\
\text { f. Motif } \\
\text { g. Peluang }\end{array}$ & $\begin{array}{l}1,2,3 \\
4,5 \\
6 \\
7 \\
8 \\
9 \\
10\end{array}$ \\
\hline 3. & $\begin{array}{l}\text { Produktivitas } \\
\text { Kerja }\end{array}$ & $\begin{array}{l}\text { Adalah sebagai rasio dari } \\
\text { keluaran (output) }\end{array}$ & $\begin{array}{l}\text { a. Pengetahuan } \\
\text { b. Keterampilan }\end{array}$ & $\begin{array}{l}1,2 \\
3,4\end{array}$ \\
\hline
\end{tabular}




\begin{tabular}{|c|c|c|c|}
\hline$(\mathrm{Y})$ & $\begin{array}{l}\text { yang dicapai } \\
\text { produktivitas atau efisiensi } \\
\text { menghendaki penentan } \\
\text { outcome dan penentu jumlah } \\
\text { sumber daya yang dipakai } \\
\text { untuk menghasilkan outcome } \\
\text { tersebut. Gomes (2012:160) }\end{array}$ & $\begin{array}{ll}\text { c. } & \text { Kemampuan } \\
\text { d. } & \text { Sikap } \\
\text { e. } & \text { Perilaku }\end{array}$ & $\begin{array}{l}5,6 \\
7,8 \\
9,10\end{array}$ \\
\hline
\end{tabular}

\section{Populasi dan Sampel}

Populasi penelitian ini adalah karyawan Bagian Produksi PT. Remco Palembang yang berjumlah 60 orang. Sugiyono (2017:81) menjelaskan sampel adalah jumlah dan karakteristik yang dimiliki oleh populasi tersebut. Penentuan jumlah sampel yang digunakan dalam penelitian ini adalah dengan metode nonprobability sampling dengan teknik sampel jenuh. Sampel jenuh adalah teknik pengambilan sampel dimana semua anggota populasi digunakan sebagai sampel. Dengan demikian sampel dalam penelitian ini berjumlah 60 orang karyawan Bagian Produksi PT. Remco Palembang.

Data primer sebagai data dalam penelitian ini yang diperoleh secara langsung dari hasil objek penelitian. Penelitian ini menggunakan teknik pengumpulan data berupa 1) observasi, dilakukan dengan cara mengamati secara langsung kinerja karyawan dalam bekerja 2) wawancara, dengan melakukan tanya jawab dengan karyawan 3) kuisioner, diberikan kepada responden untuk mengetahui tanggapan responden yang berhubungan dengan variabel penelitian.

Pernyataan yang tersedia dalam kuisioner ditanggapi oleh responden yang dihitung dengan skla pengukuran berupa Skala Likert yaitu sangat setuju dengan skor 5 , setuju dengan skor 4, ragu-ragu dengan skor 3 , tidak setuju dengan skor 2 , sangat tidak setuju dengan skor 1 .Instrumen penelitian berupa kuisioner yang diuji dengan pengujian validitas dan reliabilitas dengan software SPSS (Statistic Produc and Service Solution).

Pengujian instrumen penelitian adalah uji validitas dan uji reliabilitas. Uji validitas adalah sejauh mana ketepatan dan kecermatan suatu instrumen pengukur (tes) dalam melakukan fungsi ukurnya. Untuk menghitung uji validitas dengan membandingkan nilai correlated itemtotal correlations dengan hasil perhitungan Jika nilai $r_{\text {hitung }}$ lebih dari nilai $r_{\text {tabel }}$ dengan taraf signifikan 0,05 maka pertanyaan atau indikator tersebut valid (Priyatno 2016:143). Uji reliabilitas digunakan untuk menguji konsistensi sebagai alat ukur apakah hasilnya tetap sama atau tidak jika pengukuran diulang dan diukur dengan teknik Cronbach's Alpha. Kumpulan Butir pertanyaan dinyatakan raliabel jika koefisien reliabelnya lebih besar dari 0,8 (Priyatno 2016:156).

Teknik analisi data adalah kuantitatif dengan metode deskripsi dan assosiatif yang berguna untuk mengelompokkan data berdasarkan variabel dan jenis responden, menyajikan data tiap tabel yang diteliti, melakukan perhitungan untuk menjawab rumusan masalah dan melakukan perhitungan untuk hipotesis yang telah diajukan. Perhitungan dan pengeolahan data menggunakan SPSS. Adapun alat analisis data dalam penelitian ini adalah analisis regresi berganda, koefisien determinasi, uji asumsi klasik dan pengujian hipotesis uji $\mathrm{F}$ dn uji t. Analisis regresi linear berganda 
digunakan untuk mengetahui pengaruh variabel bebas terhadap variabel terikat. Model persamaan regresi yang digunakan adalah $\mathrm{Y}=\mathrm{a}$ $+b 1 X 1+B 2 X 2$ dimana $Y=$ produktivitas $\mathrm{a}=$ bilangan konstanta b1 dan $b 2=$ koefisien regresi $X 1=$ pengawasan dan $\mathrm{X} 2$ penilaian kinerja. Koefisien determinasi digunakan untuk menganalisis kontribusi variabel bebas terhadap variabel terikat dalam model penelitian yang menunjukkan seberapa besar variabel bebas dapat menjelaskan variabel terikat.

Uji asumsi klasik yang meliputi uji normalitas, uji multikolinearitas dan uji heteroskesdastisitas yang diselesaikan menggunakan SPSS. Uji normalitas dilakukan untuk mengetahui apakah dalam sebuah model regresi nilai residual memiliki distribusi normal atau tidak uji normalitas dilakukan dengan tabel normal One-Sample KolmogrovSmirnov. Data dikatakan normal jika nilai signifikan lebih dari 0,05 (Priyatno 2016:118)

Uji multikolinearitas digunakan untuk mengukur tingkat keeratan hubungan antara variabel bebas dengan melihat nilai tolerance dan variace inflation factor (VIF). Tidak terjadinya multikolinearitas jika nilai tolerance kurang dari 0,1 dan VIF lebih dari 10 (Priyatno (2016:129). Uji heteroskesdastisitas yaitu keadaan dimana terjadi ketidaksamaan varian dari residu untuk pengamatan pada model regresi. Untuk mendeteksi ada tidaknya heteroskedastisitas dapat dilakukan dengan melihat ada atau tidaknya pola tertentu pada grafik scatterplots antara SRESID dan ZPRED di mana sumbu $Y$ adalah yang diprediksi dan sumbu $X$ adalah residualnya $(\mathrm{Y}$ prediksi $-\mathrm{X}$ sesungguhnya). Jika tidak ada pola yang jelas serta titik-titik menyebar di atas dan di bawah angka 0 pada sumbu $Y$ maka tidak terjadi heteroskedastisitas pada data variabel (Priyatno (2016:131)

Uji $F$ dan uji t digunakan dalam pengujian hipotesis. Uji F digunakan untuk mengetahui seberapa besar pengaruh variabel bebas secara bersama-sama terhadap variabel terikat dengan bunyi Hipotesis Ho:Secara simultan, pengawasan dan penilaian kinerja tidak berpengaruh signifikan terhadap produktivitas kerja karyawan PT. Remco Palembang. Ha: Secara simultan, pengawasan dan penilaian kinerja berpengaruh signifikan terhadap produktivitas kerja karyawan PT. Remco Palembang. Kriteria Pengujian adalah Jika nilai signifikan lebih dari 0,05 maka Ho diterima dan Jika nilai signifikan kurang dari 0,05 maka Ho ditolak.

Uji t digunakan untuk mengetahui apakah variabel independen secara individual mempengaruhi variabel dependen dengan bunyi Hipotesis Ho:Secara parsial, pengawasan dan penilaian kinerja tidak berpengaruh signifikan terhadap produktivitas kerja karyawan PT. Remco Palembang Ha: Secara parsial, pengawasan dan penilaian kinerja berpengaruh signifikan terhadap produktivitas kerja karyawan PT. Remco Palembang. Kriteria pengujian adalah Jika nilai signifikan lebih dari 0,05 maka Ho diterima dan Jika nilai signifikan kurang dari 0,05 maka Ho ditolak.

\section{HASIL PENELITIAN DAN PEMBAHASAN}

\section{Karakteristik Responden}

Karyawan PT. Remco cendrung bekerja di lapangan bukan di kantor ini karena sesuai dengan sifat produk yang dihasilkan yaitu karet. Dengan demikian dapat diketahui berdasarkan jenis kelamin karyawan pada PT. Remco dominan adalah berjenis 
kelamin laki-laki sebanyak 55 orang $(91,67 \%)$, berdasarkan tingkat usia karyawan pada PT. Remco dominan adalah tingkat usia antara 31-40 tahun sebanyak 39 orang (65\%), berdasarkan tingkat pendidikan karyawan pada PT. Remco dominan adalah tingkat pendidikan SMP sebanyak 30 orang (50\%) dan berdasarkan masa kerja karyawan pada PT. Remco dominan adalah masa kerja antara 5-10 tahun sebanyak 34 orang $(56,67 \%)$

\section{Hasil Pengujian Instrumen}

Kuisioner untuk masing-masing variabel terdiri dari 10 butir. Uji validitas variabel pengawasan menghasilkan semua butir kuisioner memiliki nilai $r$ hitung yang lebih besar dari $r$ tabel sehingga semua butir kuisioner dinyatakan valid. Uji reliabilitas variabel pengawasan dengan 10 butir kuisioner yang valid memberikan nilai Cronbach's Alpha sebesar 0,807 yang berarti butir-butir instrumen penelitian reliabel, dengan demikian semua butir kuisioner dapat digunakan sebagai instrumen penelitian

Uji validitas variabel penilaian kinerja menghasilkan semua butir kuisioner memiliki nilai $r$ hitung yang lebih besar dari $r$ tabel sehingga semua butir kuisioner dinyatakan valid. Uji reliabilitas variabel penilaian kinerja dengan 10 butir kuisioner yang valid memberikan nilai Cronbach's Alpha sebesar 0,832 yang berarti butir-butir instrumen penelitian reliabel, dengan demikian semua butir kuisioner dapat digunakan sebagai instrumen penelitian

Uji validitas variabel pengawasan menghasilkan semua butir kuisioner memiliki nilai $r$ hitung yang lebih besar dari $r$ tabel sehingga semua butir kuisioner dinyatakan valid. $\mathrm{Uji}$ reliabilitas variabel pengawasan dengan 10 butir kuisioner yang valid memberikan nilai Cronbach's Alpha sebesar 0,802 yang berarti butir-butir instrumen penelitian reliabel, dengan demikian semua butir kuisioner dapat digunakan sebagai instrumen penelitian.

\section{Pengujian Asumsi Klasik}

Data yang digunakan adalah data yang berdistribusi normal dan diuji dengan uji normalitas. Tabel berikut menyajikan hasil uji normalitas.

One-Sample Kolmogorov-Smirnov Test

\begin{tabular}{|ll|r|}
\hline & & $\begin{array}{r}\text { Unstandardized } \\
\text { Residual }\end{array}$ \\
\hline $\mathrm{N}$ & Mean & 60 \\
Normal & Std. Deviation &, 0000000 \\
Parametersa,b & 3,19543958 \\
Most Extreme & Absolute &, 097 \\
Differences & Positive &, 097 \\
& Negative &,- 059 \\
Test Statistic &, 097 \\
Asymp. Sig. (2-tailed) &, $200^{c, d}$ \\
\hline
\end{tabular}
a. Test distribution is Normal.
b. Calculated from data.
c. Lilliefors Significance Correction.
d. This is a lower bound of the true significance. 
Hasil uji normalitas diperoleh nilai signifikan 0,200 lebih dari 0,05 karena nilai tersebut di atas 0,05 maka dapat disimpulkan bahwa data tersebut berdistribusi normal.
Terjadinya gejala multikolinearitas pada data penelitian berarti tidak terjadi korelasi antara variabel bebas. Tabel berikut menyajikan hasil uji multikolinearitas.

\section{Coefficients $^{\mathrm{a}}$}

\begin{tabular}{|l|r|r|}
\hline \multirow{2}{*}{ Model } & \multicolumn{2}{|c|}{$\begin{array}{c}\text { Collinearity } \\
\text { Statistics }\end{array}$} \\
\cline { 2 - 3 } & Tolerance & \multicolumn{1}{c|}{ VIF } \\
\hline -(Constant) & & \\
Pengawasan &, 996 & 1,005 \\
Penilaian Kinerja &, 996 & 1,005 \\
\hline
\end{tabular}

Hasil uji multikolinearitas variabel pengawasan diperoleh nilai tolerance sebesar 0,996 kurang dari 0,1 dan nilai VIF sebesar 1,005 lebih dari 10 dan penilaian kinerja diperoleh nilai tolerance sebesar 0,996 kurang dari 0,1 dan nilai VIF sebesar 1,005 lebih dari 10. Berdasarkan pengujian data di atas menunjukan bahwa pengawasan dan penilaian kinerja tidak terjadi multikolinearitas.

Menunjukkan terjadinya gejala heteroskedastisitas pada data penelitian berarti variabel tidak sama untuk semua pengamatan. Gambar berikut ini menyajikan hasil uji heteroskesdastisitas.

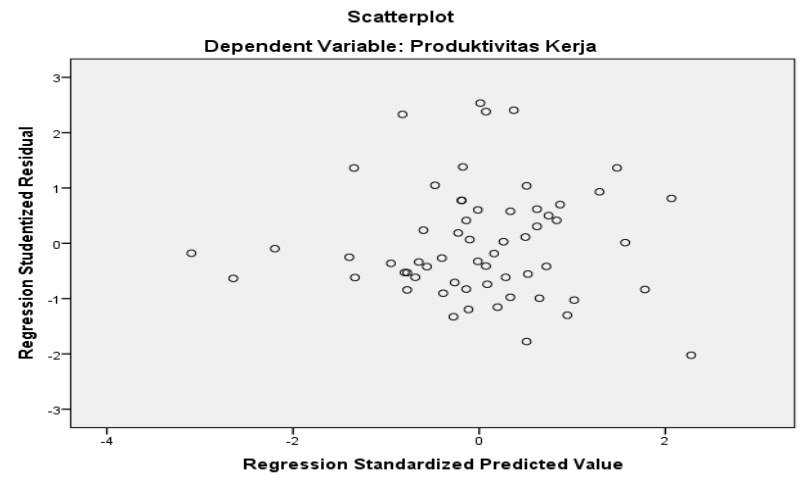

Hasil uji heteroskesdastisitas pola menyebar di atas dan di bawah angka nol pada sumbu Y. Hal ini menunjukkan bahwa data-data variabel pengawasan, penilaian kinerja dan produktivitas kerja tidak terjadi heteroskesdastisitas.

\section{Analisis Data}

Analisis koefisien determinasi adalah angka yang digunakan untuk mengetahui kontribusi yang diberikan oleh satu atau lebih variabel bebas terhadap variabel terikat. Tabel berikut menyajikan hasil pengujian koefisien determinasi. 


\begin{tabular}{|c|c|}
\hline \multicolumn{2}{|c|}{ Model Summary ${ }^{b}$} \\
\hline Model & R Square \\
\hline 1 &, 485 \\
\hline
\end{tabular}

Nilai koefisien determinasi $\mathrm{R}$ square sebesar 0,485 atau $48,5 \%$ dan sisanya $\quad(100 \%-48,5 \%) \quad 51,5 \%$ dipengaruhi oleh faktor-faktor lain yang tidak masuk dalam penelitian ini.

\section{Regresi Berganda}

Analisis regresi berganda ini bertujuan untuk mengetahui bagaimana pengaruh variabel bebas terhadap variabel terikat. Tabel berikut menyajikan hasil uji regresi linear berganda.

\section{Coefficients $^{a}$}

\begin{tabular}{|l|r|r|}
\hline \multirow{2}{*}{\multicolumn{1}{|c|}{ Model }} & \multicolumn{2}{|c|}{$\begin{array}{c}\text { Unstandardized } \\
\text { Coefficients }\end{array}$} \\
\cline { 2 - 3 } & \multicolumn{1}{|c|}{ B } & Std. Error \\
\hline (Constant) & 3,250 & 5,332 \\
Pengawasan &, 271 &, 094 \\
Penilaian Kinerja &, 656 &, 101 \\
\hline
\end{tabular}

a. Dependent Variable: Produktivitas Kerja

Persamaan regresi linear berganda adalah $Y=3,250+0,271 x_{1}+0,656 x_{2}$ Maka diketahui nilai konstanta sebesar 3,250 menunjukkan apabila tidak ada variabel independen (pengawasan dan penilaian kinerja) maka variabel dependen (produktivitas kerja) adalah sebesar 3,250 satuan. Koefisien regresi $b_{1}$ menunjukkan bahwa jika variabel pengawasan ditingkatkan sebesar satu satuan dan variabel penilaian kinerja maka produktivitas akan meningkat sebesar 0,271 satuan. Sebaliknya jika variabel pengawasan diturunkan sebesar satu satuan dan variabel penilaian kinerja maka produktivitas kerja akan menurun sebesar 0,271 satuan. Koefisien regresi $b_{2}$ menunjukkan bahwa jika variabel penilaian kinerja ditingkatkan sebesar satu satuan dan variabel pengawasan maka produktivitas akan meningkat sebesar 0,656 satuan. Sebaliknya jika variabel penilaian kinerja diturunkan sebesar satu satuan dan variabel pengawasan maka produktivitas kerja akan menurun sebesar 0,656 satuan.

\section{Pengujian Hipotesis}

Pengujian hipotesis secara simultan dengan uji $F$. Tabel berikut menyajikan hasil uji $F$.

\section{ANOVA $^{\mathrm{a}}$}

\begin{tabular}{|ll|c|}
\hline \multicolumn{1}{|c|}{ Model } & Sig. \\
\hline 1 & $\begin{array}{l}\text { Regression } \\
\text { Residual } \\
\text { Total }\end{array}$ &, $000^{\mathrm{b}}$ \\
\hline
\end{tabular}


Hasil uji $F$ diperoleh nilai signifikan 0,000 kurang dari 0,05 hasil analisis tersebut sehingga dapat disimpulkan Ho ditolak dan $\mathrm{Ha}$ diterima. Hal ini menunjukkan bahwa secara simultan, pengawasan dan penilaian kinerja berpengaruh signifikan terhadap produktivitas kerja karyawan PT. Remco Palembang.

Pengujian hipotesis secara parsial dengan uji t. Tabel berikut menyajikan hasil uji $\mathrm{t}$

\section{Coefficients $^{\mathrm{a}}$}

\begin{tabular}{|l|r|}
\hline \multicolumn{1}{|c|}{ Model } & \multicolumn{1}{|c|}{ Sig. } \\
\hline 1 (Constant) &, 545 \\
Pengawasan &, 006 \\
Penilaian Kinerja &, 000 \\
\hline
\end{tabular}

Variabel Pengawasan hasil uji t untuk variabel pengawasan diperoleh nilai signifikan 0,006 kurang dari 0,05 sehingga $\mathrm{Ho}$ ditolak dan $\mathrm{Ha}$ diterima yang berarti secara parsial, pengawasan berpengaruh signifikan terhadap produktivits kerja karyawan PT. Remco Palembang

\section{KESIMPULAN}

Berdasarkan analisis data dan pembahasan yang telah dijabarkan maka dalam penelitian ini diperoleh kesimpulan sebagai berikut:

1. Berdasarkan pengujian hipotesis dengan uji $F$, diperoleh nilai sig 0,000 atau kurang dari 0,05 yang berarti $\mathrm{Ho}$ ditolak dan $\mathrm{Ha}$ diterima maka dapat disimpulkan bahwa secara simultan pengawasan dan penilaian kinerja berpengaruh signifikan terhadap produktivitas kerja karyawan pada PT. Remco Palembang.

2. Berdasarkan pengujian hipotesis dengan uji t, diperoleh nilai sig 0,006 atau kurang dari $\mathbf{0 , 0 5}$ yang berarti Ho ditolak dan Ha diterima maka dapat disimpulkan bahwa secara parsial pengawasan berpengaruh signifikan terhadap produktivitas
Variabel Penilaian Kinerja hasil uji $t$ untuk variabel penilaian kinerja diperoleh nilai signifikan 0,000 kurang dari 0,05 maka Ho ditolak dan $\mathrm{Ha}$ diterima yang berarti secara parsial, penilaian kinerja berpengaruh signifikan terhadap produktivitas kerja karyawan PT. Remco Palembang.

kerja karyawan pada PT. Remco Palembang.

3. Berdasarkan pengujian hipotesis dengan uji t, diperoleh nilai sig $\mathbf{0 , 0 0 0}$ atau kurang dari 0,05 yang berarti Ho ditolak dan Ha diterima maka dapat disimpulkan bahwa secara parsial, penilaian kinerja berpengaruh signifikan terhadap produktivitas kerja karyawan pada PT. Remco Palembang.

\section{DAFTAR PUSTAKA}

Bintang, H, Debbi. 2016. Pengaruh Penilaian Kinerja Dan Pengembangan Karyawan Terhadap Produktivitas Karyawan (Kasus PT Bank Sumut, Cabang Sidikalang). Jurnal (online). Universitas Riau. Vol. 3 No. 22016. 
Dona, Rama. 2018. Pengaruh Penilaian kinerja Terhadap Produktivitas Kerja pegawai dikantor BPKAD Kbaupaten Kurai Timur. Jurnal (online). Volume 2 No.2 2018.

Gomes, Faustino Cardoso. 2012. Manajemen Sumber Daya Manusia. Andi. Yogyakarta.

Handayaningrat, Soewarno. 2010. Pengantar Studi IImu Administrasi Dan Manajemen. Jakarta: Gunung Agung.

Handoko, T, Tani. 2009. Manajemen. Cetakan duapuluh. Yogyakarta: Penerbit BPFE.

T, Tani. 2014. Manajemen Personalia dan Sumber Daya Manusia. Yogyakarta BPFE.

Hasibuan, Malayu, S,P. 2009. Manajemen Dasar, Pengertian dan Masalah. Edisi Revisi. Jakarta: Bumi Aksara.

Malayu, S,P. 2010. Manajemen Sumber Daya Manusia. Jakarta : Bumi Aksara.

Husein, Umar. 2013. Manejemen Personalia. Cetakan Kesebelas. BPFE. Yogyakarta.

Karmila, Hesti \& Suryalena. 2018. Pengaruh Pengawasan Dan Penilaian Kinerja Terhadap Produktivitas Kerja Karyawan Perkebunan (Studi Kasus Karyawan Bagian Produksi Pada PTPN V Sei Buatan. Jurnal (online).Universitas Riau. Vol. 5 Edisi II 2018.

Legawati, Kartika. 2014. Pengaruh pengawasan terhadap produktivitas kerja Karyawan Pabrik ( Kasus Karyawan Bagian Produksi PT. Pelita
Agung Agrindustri di Duri). Jurnal (online). Universitas Riau. Volume 1 No.2 2014.

Mangkunegara, AA Anwar. 2011. Manajemen Sumber Daya Perusahaan. Bandung: PT. Remaja Rosdakarya

Marwansyah. 2012. Manajemen sumber daya manusia. Bandung : Alfabeta.

Murnawantika, Dian. 2014. Pengaruh Pengawasan Terhadap Produktivitas Kerja Karyawan Pada CV. Putra Kaltim di Samarinda. Jurnal ilmu Administrasi Bisnis, Volume 2, Nomor 4, 2014.

Notoatmodjo, $\quad$ Soekidjo. 2009. Pengembangan Sumber Daya Manusia. Jakarta. Organisasi. Yogyakarta.

Priyanto, Duwi. 2016. Belajar Alat Analisis Data Dan Cara Pengolahannya Dengan Spss. Yogyakarta: Gava Media.

Sayuti. 2013. Manajemen Kantor Praktis. Bandung: Alfabeta.

Sedarmayanti, 2010. Sumber Daya Manusia Dan Produktivitas Kerja. Cetakan Kedua. Penerbit Mandar Maju: Bandung.

Sinungan Muchdarsyah. 2014. Produktivitas: Apa Dan Bagaimana. Jakarta: Bumi Aksara.

Siregar, Syofian. 2014. Metode Penelitian Kuantitatif. Jakarta: Kencana.

Sugiyono. 2016. Metode Penelitian Kuantitatif, Kualitatif dan Kombinasi (Mixed Methods). Bandung: Alfabeta. 
2017. Metode Penelitian Kuantitatif, Kualitatif dan R\&D. Bandung: Alfabeta.

Sujarweni, V. Wiratna. 2015. Akuntansi Manajemen. Yogyakarta: Pustaka Baru Press.

Sukarna. 2011. Dasar-Dasar manajemen. Bandung: CV. Mnadar Maju.

Sutabri, Tata. 2016. Sistem Informasi Manajemen. Yogyakarta: Andi Offset.

Sutrisno, Edy. 2015. Manajemen Sumber Daya Manusia. Cetakan Ke Tujuh. Jakarta: Kencana Prenada Media Group.

Suwatno, \& Priansa, Donni Juni. 2011. Manajemen Sumber Daya Manusia, Dalam Organisasi
Publik Dan Bisnis. Bandung: Alfabeta.

\& Priansa, Donni Juni 2013, Manajemen Sumber Daya Manusia Dalam Organisasi Publik Dan Bisnis. CV. Alfabeta: Bandung.

Umam, Kharul. 2014. Manajemen Perkantoran. Bandung. CV. PustakaSetia.

Univ. PGRI. 2019. Pedoman Penulisan Skripsi. Univ. PGRI FE. Palembang.

Wibowo. 2011. Manajemen Kinerja. Jakarta. PT. Raja Grafindo Persada.

Wibowo. 2014. Manajemen Kinerja. Edisi Revisi. Jakarta: PT. Raja Grafindo Persada 